\title{
What impact does oocyte vitrification have on epigenetics and gene expression?
}

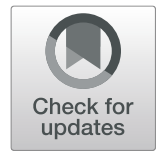

\author{
Julie Barberet ${ }^{1}$, Fatima Barry ${ }^{1}$, Cécile Choux², Magali Guilleman¹, Sara Karoui', Raymond Simonot ${ }^{1}$, \\ Céline Bruno ${ }^{1}$ and Patricia Fauque ${ }^{1^{*}}$ (D)
}

\begin{abstract}
Children conceived by assisted reproductive technologies (ART) have a moderate risk for a number of adverse events and conditions. The question whether this additional risk is associated with specific procedures used in ART or whether it is related to the intrinsic biological factors associated with infertility remains unresolved. One of the main hypotheses is that laboratory procedures could have an effect on the epigenome of gametes and embryos. This suspicion is linked to the fact that ART procedures occur precisely during the period when there are major changes in the organization of the epigenome. Oocyte freezing protocols are generally considered safe; however, some evidence suggests that vitrification may be associated with modifications of the epigenetic marks. In this manuscript, after describing the main changes that occur during epigenetic reprogramming, we will provide current information regarding the impact of oocyte vitrification on epigenetic regulation and the consequences on gene expression, both in animals and humans. Overall, the literature suggests that epigenetic and transcriptomic profiles are sensitive to the stress induced by oocyte vitrification, and it also underlines the need to improve our knowledge in this field.
\end{abstract}

Keywords: DNA methylation, Epigenetics, Gene expression, Oocyte, Vitrification

\section{Background}

Since their introduction, medically assisted reproductive technologies (ARTs) have allowed millions of children to be born to infertile couples, accounting for 2 to $6 \%$ of births in Europe [1, 2]. Although generally recognized as safe, associations exist between ARTs and an increased incidence of low birth weight, birth defects, growth and metabolic disorders, and psychomotor or mental developmental delays [3]. More specifically, there has been an increase in the occurrence of rare diseases related to genomic imprinting, such as Beckwith-Widemann syndrome, Angelman syndrome, and Silver-Russell syndrome [4]. ART could be detrimental to epigenetic reprogramming of gametes and pre-implantation

\footnotetext{
* Correspondence: patricia.fauque@chu-dijon.fr

${ }^{1} \mathrm{CHU}$ Dijon Bourgogne, Laboratoire de Biologie de la Reproduction, CECOS, 14 rue Gaffarel, 21079 Dijon Cedex, France

Full list of author information is available at the end of the article
}

embryos, leading to potential effects after birth [5]. The periconception period-gametogenesis, fertilization, and early embryonic development-is a time of physiologically intense epigenetic reprogramming $[6,7]$.

Cryopreservation of oocytes by "slow freezing" was initiated in the 1980s, and the first birth was obtained in Japan more than 30 years ago [8]. However, one of the main difficulties with this technique is that oocyte survival rates have remained low, around $60 \%$ post-thaw [9]. The appearance of oocyte vitrification has subsequently completely revolutionized this field. Many studies have proven that oocyte survival rates, fertilization rates, and embryonic cleavage were higher after vitrification than after slow freezing, and the results with vitrification may even be equivalent to the results obtained with fresh oocytes [10-18].

In view of the growing number of children conceived thanks to oocyte vitrification and the absence of birth 
defects in these children [19-21], it is now considered by many countries as the first-line technique to preserve female fertility [22]. Obviously, it is used in women who need potentially sterilizing treatment or whose fertility may be prematurely impaired. Oocyte vitrification is also on the rise in the context of intra-couple ART management; it is often used in the event of failed sperm collection or when there is a preference for the storage of oocytes rather than embryos [23]. In addition, it could be chosen in the context of oocyte donation program, but also in some countries where the law prohibits embryo cryopreservation. Finally, some countries have expanded the use of oocyte freezing for purpose of postponing pregnancy for personal or professional reasons, also known as "delayed childbearing" [24].

It is therefore important that the technique used for freezing oocytes is not harmful for future pregnancies or the health of children that may be obtained from these oocytes. However, pregnancy outcomes from vitrified oocytes vary between centres, who use different techniques and whose operators have different levels of expertise [14]. There is usually a shallow learning curve for oocyte vitrification techniques, resulting in a maximum survival rate of no more than $70-80 \%$ [14]. Furthermore, it has been reported in mammals that oocyte vitrification could reduce the potential for embryonic development [25-27]. The effects of vitrification can be at the molecular level and may influence epigenetic control, especially since these processes coincide with the reprogramming of the oocyte epigenome. Besides, the challenge for the oocyte is the synthesis and preservation of all transcripts (in particular expression of epigenetic modifier enzymes) needed to fulfil protein requirements during the period of meiotic completion, fertilisation, and the oocyte-embryo transition [28]. During oogenesis, the transcription influenced by epigenetic factors is intense. The growth phase is succeeded by a phase of resumed meiotic activity and transcriptional silencing [28] in which changes in gene expression depend on translation and degradation of transcripts. This is crucial for assembling the molecular machinery, in particular, the transcripts involved in epigenetic mechanisms, required for meiotic progression, fertilization, and embryo development $[29,30]$. The transcripts content shows that temporal changes are mostly regulated via epigenetic mechanisms and associated with oocyte competencies [31]. Therefore, any factors, herein potentially linked to the vitrification procedures (consequences of chilling and high concentrations of cryoprotectants), that influence genome integrity [32] and transcripts synthesis/repression, stability, and association with the translation machinery can have a major impact on protein expression and crucial biological processes.

In this manuscript, after describing (1) the epigenetic marks controlling gene transcription as well as the major epigenetic events that occur during gametogenesis and (2) gene expression regulation through small RNAs, we will discuss the current state of knowledge of the impact of oocyte vitrification on epigenetic regulation and the consequences on gene expression.

\section{Epigenetic reprogramming during oogenesis}

Epigenetics refers to the processes leading to the diversification of the expression of genetic material in a heritable manner during cell divisions and without modifying the nucleotide sequences. These mechanisms, which occur during development, are numerous and complex and directly or indirectly influence the state of chromatin. DNA methylation appears as a major epigenetic mark involving a covalent modification of DNA. Indeed, DNA methylation is a biochemical process where a methyl group from the donor S-adenosyl methionine is added at the carbon- 5 position of cytosine $(5 \mathrm{mC})$ in the cytosine-guanine $(\mathrm{CpG})$ dinucleotide by DNA methyltransferases (DNMTs) and can be erased by $5 \mathrm{mC}$ oxydases (ten-eleven translocation proteins: TET), through sequential oxidation of $5 \mathrm{mC}$ to 5hydroxymethylcytosine $(5 \mathrm{hmC}), 5$-formylcytosine $(5 \mathrm{fC})$, and finally, 5-carboxylcytosine $(5 \mathrm{caC})[33,34]$. Within the context of chromatin, DNA methylation does not function alone. Instead, there is a complex interplay between DNA methylation and post-translational biochemical histone modifications (mainly localized in the $N$-terminal tails) known as the "histone code" [35]. Together, they control chromatin accessibility and packaging, resulting in gene activation or repression.

Epigenetic marks are also involved in the fine regulation of a small group of genes called "imprinted genes" (about 150 described in mice, and about half of these genes have been found in humans [36, 37]). These genes have a monoallelic expression that is dependent on the parental origin of the allele. The parental imprint is linked to differential epigenetic labeling of parental alleles, established during gametogenesis. Mature gametes then transmit their own parental epigenome, which is maintained during successive cell divisions after fertilization. This phenomenon affects different regions and plays a major role in the development and growth of the conceptus.

Beyond being essential for the acquisition and maintenance of gametic identity, pluripotency embryonic lineage decisions, and genomic imprinting, reprogramming of the epigenome is crucial for the control of repeated sequences, especially transposable elements (TEs) $[38,39]$. TEs represent more than half of the human genome [40,41]. Some of these elements, retrotransposons in particular, have retained some level of activity (even in the human embryo, as reported by Grow et al.) [42] and the ability to move [43]. Consequently, they can 
have an impact on gene organization and expression, for instance, initiating chromosomal rearrangements and gene mutations/deletion/duplication or inappropriate gene expression [38, 44, 45]. Indeed, experimental overexpression of on type of transposable element (a nonlong terminal repeats [LTRs] sub-type: LINE-1) in mouse oocytes results in oocyte aneuploidy and embryonic lethality [46]. Therefore, the organism has developed several defence mechanisms to silence some TEs, such as the methylation of DNA, histone modifications, and regulation by small RNAs [47].

More generally, the facts that some TEs are sensitive to environmental factors that can mediate their mobilization and that epigenetic modifications are also sensitive to the environment suggest that both can work together [47], underscore the importance to determine whether some reproductive procedures such as oocyte vitrification could perturb transposable element control during this critical window of development. Otherwise, in the oocyte, LTRs, another subtype of transposable elements, are highly expressed, very active, and can regulate host genes, notably by contributing to the generation of hypermethylated domains downstream [48-50].

\section{DNA methylation}

In mammals, DNA methylation of CpG sites is generally high across gene bodies and inter-genic regions, with low or intermediate DNA methylation observed almost solely at regulatory regions, such as promoters and enhancers [51]. DNA methylation in CpGs sequence is indeed one of the main epigenetic mechanisms for the regulation of gene expression [52]. Certain regions of the genome contain clusters of CpG sequences (2001000 bp in length), termed CpG islands (CGI), which are usually unmethylated and associated with gene transcription regulation [53, 54]. The CGI is mostly found in gene promoter regions in which DNA methylation can modify gene expression by regulating the recruitment of methylated DNA-binding proteins or by changes in the accessibility of the DNA sites, which influence transcription factor binding and overall chromatin structure [53, 54]. Commonly, DNA methylation of the promoter regions is generally associated with gene silencing, although this rule is not valid for promoters with low CpG density [55]. Furthermore, the methylation status of enhancers exhibiting widespread hypo-methylation during development [56], and for which interactions with promoters could be blocked by insulators, is also key to controlling gene expression in development and cell function [51, 57]. Therefore, DNA methylation is involved in many important epigenetic processes, such as mammalian development and cellular reprogramming and retrotransposon silencing, as reported above [58]. It is also one of the major mechanisms for initiating and maintaining parental imprinting. These imprinted genes are generally grouped into loci where each has regions that exhibit allele-specific differences in methylation, called differentially methylated regions (DMRs). Within these DMRs, imprinting control regions (ICRs) participate in the regulation of other genes that are subject to imprinting within the same locus (ICRs' differential methylation patterns established in the gametes). Furthermore, CGI methylation during oocyte growth is not exclusively associated with genomic imprinting, but it determines a significant proportion of the genomic DNA methylation profile inherited by the preimplantation embryo $[59,60]$ beyond them are required to maintain transcriptional repression at a cluster of testis-specific genes or to repress brain-specific genes during embryonic development [60].

Thanks to new technologies which make it possible to analyze the epigenome from a few cells, major epigenetic events throughout the fetal and preimplantation periods (long based on data obtained in the mouse model) have been decoded in humans, particularly those related to DNA methylation [6, 61] (Fig. 1). In short, the primordial germ cells (PGC) will undergo a significant demethylation of their genome during the first weeks of development (levels are less than 10\%) [62]. After the period of DNA demethylation, male germ cells initiate and complete remethylation during prenatal development until puberty through de novo DNA methyltransferase Dnmt3A and its cofactor, Dnmt3L [63-65]. In contrast, oocytes in the female arrested at the prophase of meiosis I remain hypomethylated throughout the fetal period [63-65]. DNA methylation will only be acquired by the same enzymatic machinery as that in male germ cells $[66,67]$ in the post-pubertal period during each cycle and in each cohort of oocytes engaged towards ovulation from the primary stage to the antral follicle stage [68]. The fact that this marking is gradually established throughout oocyte growth and that some methylation marks are not established until the final stages of the oocyte [59] draws attention to the potential deregulations induced by reproductive techniques, in particular, controlled ovarian hyperstimulation which aims to obtain several mature oocytes or in vitro oocyte maturation, and also potentially during the oocyte manipulations required in the oocyte freezing protocol [68]. It is interesting to note that ART children with BeckwithWiedemann syndrome all have methylation alterations carried by the maternal allele [69].

Following fertilization, the parental genome undergoes a massive second wave of demethylation (the paternal genome is actively demethylated, and the maternal genome passively demethylated [70]) to establish the pluripotency that is required to develop embryonic lineages. In contrast, the ICRs of imprinted genes escape 


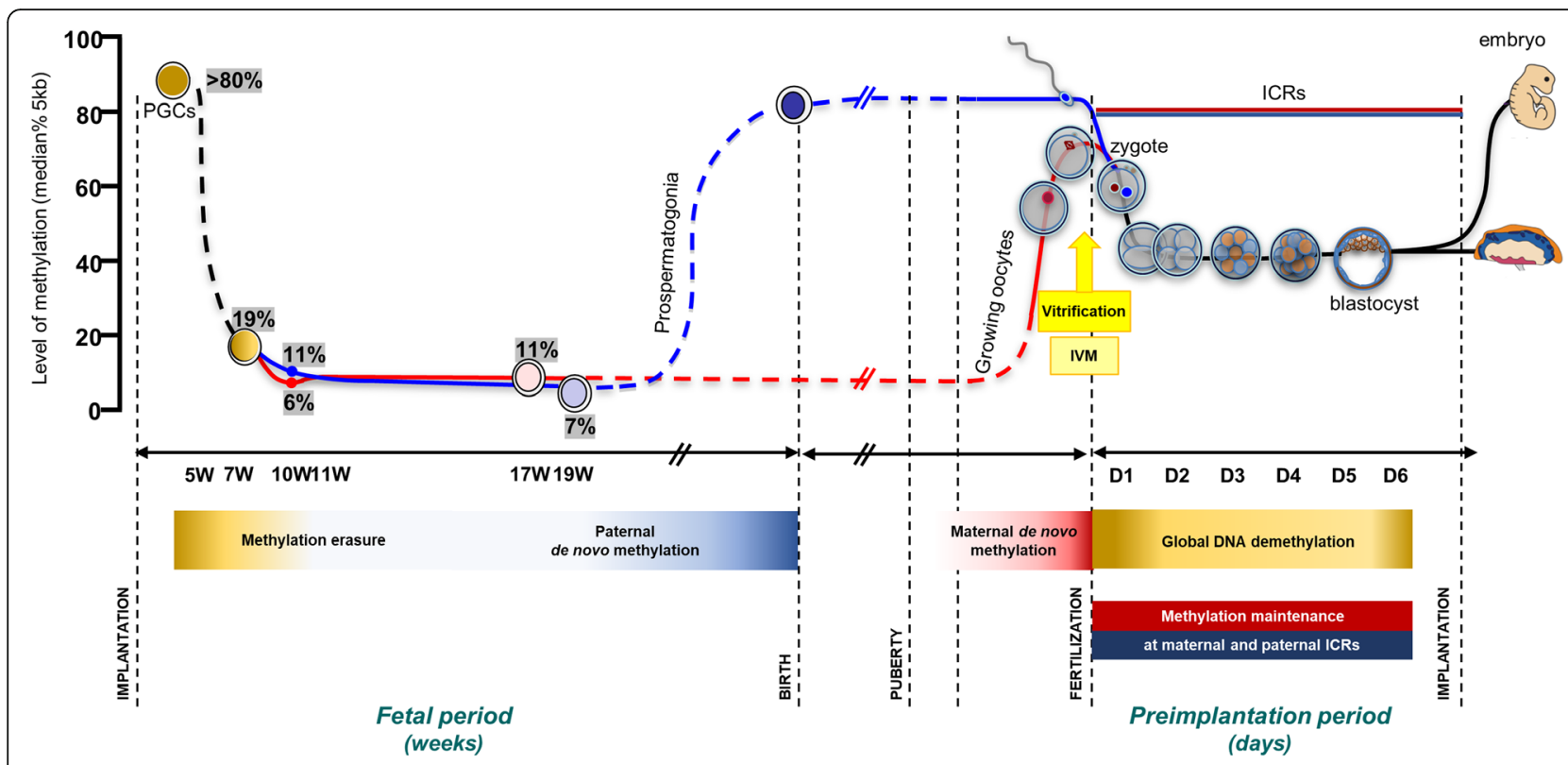

Fig. 1 The timing of vitrification (associated or not with oocyte in vitro maturation) coincides with DNA methylation changes taking place during gametogenesis and embryogenesis. DNA methylation changes described in humans are represented here through full lines. The progenitors of the mouse and human germline (PGCs, Primordial Germ Cells) undergo a marked first genome-wide DNA demethylation. The gametic re-methylation will then be different between the two sexes. Indeed, on the male side, de novo methylation of germ cells is initiated and almost complete during prenatal development while on the female side, oocytes remain hypomethylated throughout the fetal period. After the puberty, DNA methylation is then acquired during the growing phase of the oocyte cohort. Following fertilization, maternal and paternal epigenomes introduced by the gametes must be reset a second time (second wave of demetylation) to establish the pluripotency that is required for development embryonic lineages. However, methylation of DNA acquired in the germ line at the ICRs will be maintained after fertilization to ensure sex-specific and monoallelic expression of imprinted genes

demethylation thanks to the action of DNA methyltransferase 1 (Dnmt1) [71] and the KRAB zinc-finger protein 57 (ZFP57) protection. Oocyte ICRs are composed of CGIs enriched for a specific CG-rich hexanucleotide sequence (TGCCGC) recognised by the ZFP57 which protects imprinted sites against the wave of DNA demethylation during the embryonic reprogramming by recruiting KAP1 and other effectors [72, 73]. Thus, parental-specific DNA methylation of ICRs is acquired in the germline and must remain after fertilization.

The re-methylation of the genome then occurs in the cells of the inner cell mass of the blastocyst under the action of Dnmts [61]. All of the epigenetic modifications taking place in the embryo depend heavily on the level of epigenetic modifier enzymes expressed from maternally stored mRNAs during oocyte growth. One that is specifically inherited from the oocyte is Dnmt1o, an oocyte-derived isoform of Dnmt1 [74]. Dnmt1o, which is only expressed in oocytes and preimplantation embryos, is involved in the methylation maintenance of imprinted loci and is important for normal embryo development [75]. Disruptions in DNMT1o-dependent maintenance methylation have been suggested to explain the mosaic DNA hypomethylation at multiple imprinted loci associated with ART [76]. In humans, DNMT1o's crucial role in maintaining methylation in early embryos has also been highlighted [77].

Furthermore, one of the major functions of DNA methylation is the silencing of retrotransposons in order to ensure normal meiosis and the preservation of genomic integrity in the oocyte [47]. However, some TEs could also be important in the contribution of intragenic DNA methylation in gametic DNA methylome. A recent study in mouse, rat, and human oocytes identified that $18 \%, 12 \%$, and $11 \%$ of all DNA methylation, respectively, is linked to transcription initiated at LTRs [78]. Remarkably, LTR-dependent DNA methylation, which in mouse oocytes coincides with transcription-coupled H3K36me3 deposition [79], shows strong species specificity and can be inherited by blastocyst or extraembryonic tissues [78]

\section{Histone modifications}

Post-translational histone modifications (found at promoters or gene bodies) represent a much more complex transcriptional control system, combining more than seventy biochemical modification sites and a few hundred proteins catalyzing the addition or removal of these modifications. Histones are proteins associated with DNA that allow DNA compaction and three-dimensional chromatin organization (structural unit of chromatin: the 
nucleosome, composed of an octamer of histones [4 histones in two copies each $\mathrm{H} 2 \mathrm{~A}, \mathrm{H} 2 \mathrm{~B}, \mathrm{H} 3$, and $\mathrm{H} 4]$ on which $147 \mathrm{bp}$ of DNA is wound). These post-translational enzymatic changes occur in the terminal tails of the histones. The major histone tail modifications are acetylation and methylation, but other potential biochemical modifications exist such as ubiquitination and phosphorylation on specific histone amino acids (lysine can be acetylated, methylated, or ubiquitinated; arginine can be methylated, and serine and threonine can be phosphorylated). Each combination of biochemical modifications (type, position, and number of modifications on histone amino acids) is associated with a particular state of chromatin compaction and thus correlates with different biological effects (transcriptional repression or activation) [80, 81].

Basically, when DNA is methylated, lysine 9 of histone $\mathrm{H} 3$ is di- or tri-methylated (H3K9me2/me3), chromatin is compacted, and transcription is blocked. On the contrary, when DNA is demethylated, lysine 9 of histone $\mathrm{H} 3$ is acetylated and lysine 4 of histone $\mathrm{H} 3$ is di- or trimethylated (H3K4me2/me3), chromatin is relaxed, and transcription is facilitated.

Much like DNA methylation, post-translational histone modifications are highly dynamic during oogenesis [82] and preimplantation embryo development [83]. For instance, in early-stage growing oocytes, H3K4me3 appears as a canonical pattern at promoters, whereas H3K27me3 appears as a non-canonical form (variant: ncH3K27me3) in regions lacking transcription [84]. Non-canonical H3K4me3 appears at later stages and becomes dominant in mature oocytes. It is broadly deposited in partially methylated domains (which are nontranscribing regions) as $\mathrm{H} 3 \mathrm{~K} 27 \mathrm{me} 3$ but in nonoverlapping subregions [84].

In contrast to oocytes, sperm DNA is mainly packaged by protamines, although it is recognized that a significant proportion of chromatin retains histones which are localized mainly on developmentally important genes [85]. After fertilisation, the spermatic protamines are exchanged for newly synthesized histones derived from the ooplasm [86]. The histone marks (such as H3K4me3 and H3K27me3) seem to be erased more rapidly on the paternal genome than on the maternal genome [87]. The retention of histone marks from the oocyte in the early embryo (two-cell stage) has been evidenced for broad H3K4me3 domains (cover 22\% of the oocyte genome) [88]. These large domains become restricted to transcription start sites at embryonic genome activation stage. The active restriction of these broad H3K4me3 domains is required for normal embryo genome activation and further development [89]. In addition, oocyte ncH3K27me3 is specifically removed at developmental gene promoters while oocyte ncH3K27me3 at distal sites persists until the blastocyst stage (inner cell mass) [90].
On the other hand, H3K4me3 and H3K27me3 from sperm (mostly in canonical form) are erased after fertilization, re-established during early development in low levels at broad domains, and then removed at the two-cell (H3K4me3) or epiblast (H3K27me3) stages [88, 90]. Therefore, many of the histone marks inherited in embryos are from the maternal genome and can have important functions during early development.

Histone modifications have also recently been recognized as playing a key role in the regulation of TEs. Transcriptionally, silent TEs are often associated with repressive histone lysine methylation marks (H3K9, H3K27, and H4K20) and histone H2A.Z; however, different marks are specifically enriched in different TEs and cell types [91].

\section{Epigenetic information through small RNAs}

Aside from epigenetic controls, non-coding RNAs (ncRNAs) also control several levels of gene expression [92] and have important roles in signalling networks and the epigenome [93]. There are two types: small RNAs and long non-coding RNAs (lncRNAs). LncRNAs are longer than the arbitrary limit of 200 nucleotides and do not encode proteins [94]. LncRNAs have been implicated in pluripotency and differentiation, and namely in the $\mathrm{x}$-inactivation process through Xist and Tsix lncRNAs expressed in oocytes and early embryos [95, 96]. Interestingly, lncRNAs expression is also tightly linked with retrotransposons [97]. Small RNAs include microRNAs (miRNAs), small interfering RNAs (siRNAs), and piwi-interacting RNAs (piRNAs). The miRNAs have emerged as powerful post-transcriptional regulators in gene expression. With an average of 22 nucleotides, miRNAs mostly interact with the 3 ' untranslated region (3' UTR) of target mRNAs to initiate mRNA degradation and repress translation and transcription [98]. miRNAs, endogenous small interfering RNAs (endo-siRNAs), and piRNAs are the major types of small RNAs found in mammalian oocytes and early embryos [99].

The presence of miRNAs has been confirmed throughout the growth and maturation of mammalian oocytes [100], and they have a critical role in the physiology and developmental competence of mammalian oocytes and embryos. Furthermore, a recent review provided evidence that aberrant miRNA expression in female reproductive cells and embryos is associated with infertility and embryogenesis defects [101].

miRNAs and piRNAs are required for male germline retrotransposon control [38, 102]. For meiosis and retrotransposon silencing in oocytes, a subclass of siRNAs (endogeneous-siRNAs) known to regulate transcripts $[103,104]$ is necessary $[105,106]$. However, an oocytespecific piRNA family (os-piRNAs) may also be involved in the silencing of TEs, as revealed in human oocytes 
[107]. The repression of transposable elements is indeed important for oogenesis, seeing as a higher proportion of oocytes from mice expressing elevated levels of retrotransposons undergo apoptosis during meiotic prophase I [108]. However, the small RNAs required for transposon control could be different in non-murine mammals (including humans), and there is a possibility that piRNAs play a more important or essential role in oogenesis [105]. The functions of these small RNAs underline their importance in the oocyte. However, as reported above, they have been largely underestimated and limited to studies of miRNAs.

\section{Impact of oocyte vitrification on epigenetic regulators \\ DNA methylation}

Only three studies have been conducted in humans, two of which were conducted using an immunofluorescence (IF) technique, which is a crude way of measuring global DNA methylation state based on the detection of $5 \mathrm{mC}$ (Table 1) [109-111]. The third one performed targeted DNA methylation analyses of two selected imprinted genes by using pyrosequencing. One study analyzed the consequences of oocyte vitrification on embryonic methylation levels [110], while the other two studies analyzed the impact of germinative vesicle vitrification on in vitro matured oocytes. In summary, no differences have been reported in humans (Table 1, Fig. 2).

In animals, the studies were conducted mainly in cattle and murine animals (Table 2). The studies used various techniques and targeted very different gene categories, so we cannot currently draw strong conclusions relative to the epigenetic impact of oocyte vitrification. Two studies in cattle found a decrease in overall IF methylation after oocyte vitrification $[112,115]$, while the analysis of three genes subjected to imprinting did not reveal any significant differences [113].

In an analysis of DNA methylation focused on the enzymes involved in epigenetic changes, Zhao et al. found no differences [114]. Finally, analysis of the methylation levels of pluripotency gene promoters showed that oocyte vitrification did have an effect [117] (Table 2). At the blastocyst stage from vitrified oocytes, a decrease in methylation levels may be observed $[112,113]$. This decrease appears to be predominant within the trophectoderm [112].

\section{Histone modifications}

These analyses have only been conducted in animals (Table 2), and the results are complex to interpret because different histone modifications were studied.

However, it seems that oocyte vitrification leads to an increase in the acetylation levels of histones ( $\mathrm{H} 4$ and H3) $[116,118,119]$ though it should be noted that the opposite was found in the trophectoderm [112]. The reported results concerning the methylation levels of histone H3K9 are also inconsistent (Table 2).

\section{MicroRNAs}

A recent study conducted in mice reported the comparison of miRNA transcriptome in fresh and vitrified oocytes [120]. Twenty-two miRNAs were differentially expressed between the two groups, and most of the target genes regulated by these miRNAs were identified as "metabolic pathway" regulators. Among them, miR-134$5 p$, miR-210-5p, and miR-21-3p were significantly upregulated, whereas miR-465c-5p was downregulated. The expression of potential target PTEN, regulating cell apoptosis through oxidative stress, was reduced [120].

\section{Impact of oocyte vitrification on gene expression}

In humans, only one study has compared the gene expression profiles of fresh and vitrified non-fertilized human oocytes using a microarray approach [121] (Table 3). The authors observed the downregulation of many genes in the ubiquitination pathway, including members of the ubiquitin-specific peptidase family and subunits of the $26 \mathrm{~S}$ proteasome.

Three studies have been conducted on supernumerary mature oocytes and expressional analysis of targeted

Table 1 Impact of oocyte vitrification on DNA methylation in humans

\begin{tabular}{|c|c|c|c|c|c|}
\hline References & Materials & $\begin{array}{l}\text { Number of oocytes and } \\
\text { embryos }\end{array}$ & $\begin{array}{l}\text { Technology of } \\
\text { assessment }\end{array}$ & $\begin{array}{l}\text { Studied } \\
\text { sequences }\end{array}$ & Conclusions \\
\hline $\begin{array}{l}\text { Liu et al. } \\
{[109]}\end{array}$ & $\begin{array}{l}\text { Vitrified MII, } \\
\text { MII from IVM, } \\
\text { GV }\end{array}$ & $\begin{array}{l}56 \text { in vivo MII, } 106 \mathrm{MII} \\
\text { after MIV, } 122 \text { MII from } \\
\text { vitrified GV }\end{array}$ & $\begin{array}{l}\text { Immunofluorescence } \\
(5 \mathrm{mC})\end{array}$ & $\begin{array}{l}\text { Global } \\
\text { analysis }\end{array}$ & $\begin{array}{l}\text { No significant differences in fluorescence intensities } \\
\text { between the three oocyte groups }\end{array}$ \\
\hline $\begin{array}{l}\text { De Munck } \\
\text { et al. [110] }\end{array}$ & $\begin{array}{l}\text { Mll from } \\
\text { donated } \\
\text { oocytes, } \\
\text { sibling cohort }\end{array}$ & $\begin{array}{l}31 \text { embryos (D3) from } \\
17 \text { fresh MII and } 14 \\
\text { vitrified MII }\end{array}$ & $\begin{array}{l}\text { Immunofluorescence } \\
(5 \mathrm{mC}, 5 \mathrm{hmC})\end{array}$ & $\begin{array}{l}\text { Global } \\
\text { analysis }\end{array}$ & $\begin{array}{l}\text { No significant differences in fluorescence intensities } \\
\text { between embryos from fresh and vitrified oocytes } \\
(5 \mathrm{mC} 1.0 \pm 0.49 \text { vs } 0.83 \pm 0.41 ; 5 \text { hmC } 1.0 \pm 0.40 \text { vs } \\
0.81 \pm 0.36)\end{array}$ \\
\hline $\begin{array}{l}\text { Al-Khtib } \\
\text { et al. [111] }\end{array}$ & $\begin{array}{l}\text { MII from IVM } \\
\text { (GV donated } \\
\text { for research) }\end{array}$ & $\begin{array}{l}77 \text { MIl after IVM from } \\
184 \text { vitrified VG, and } 85 \\
\text { MII from } 120 \text { fresh GV }\end{array}$ & Pyrosequencing & $\begin{array}{l}\text { H19 (pool of } 3 \\
\text { oocytes) and } \\
\text { KCNQ1OT1 }\end{array}$ & $\begin{array}{l}\text { Oocyte vitrification at the GV stage does not affect } \\
\text { the methylation profiles of H19-DMR et KvDMR1 of } \\
\text { the in vitro matured oocytes }\end{array}$ \\
\hline
\end{tabular}

$D$ day of embryo culture, GV oocyte at germinal vesicle stage, $5 \mathrm{hmC}$ 5-hydroxymethylCytosine, $\mathrm{VM}$ in vitro maturation, $5 \mathrm{mC} 5$-methylCytosine, $\mathrm{MIl}$ oocyte at metaphase II stage 


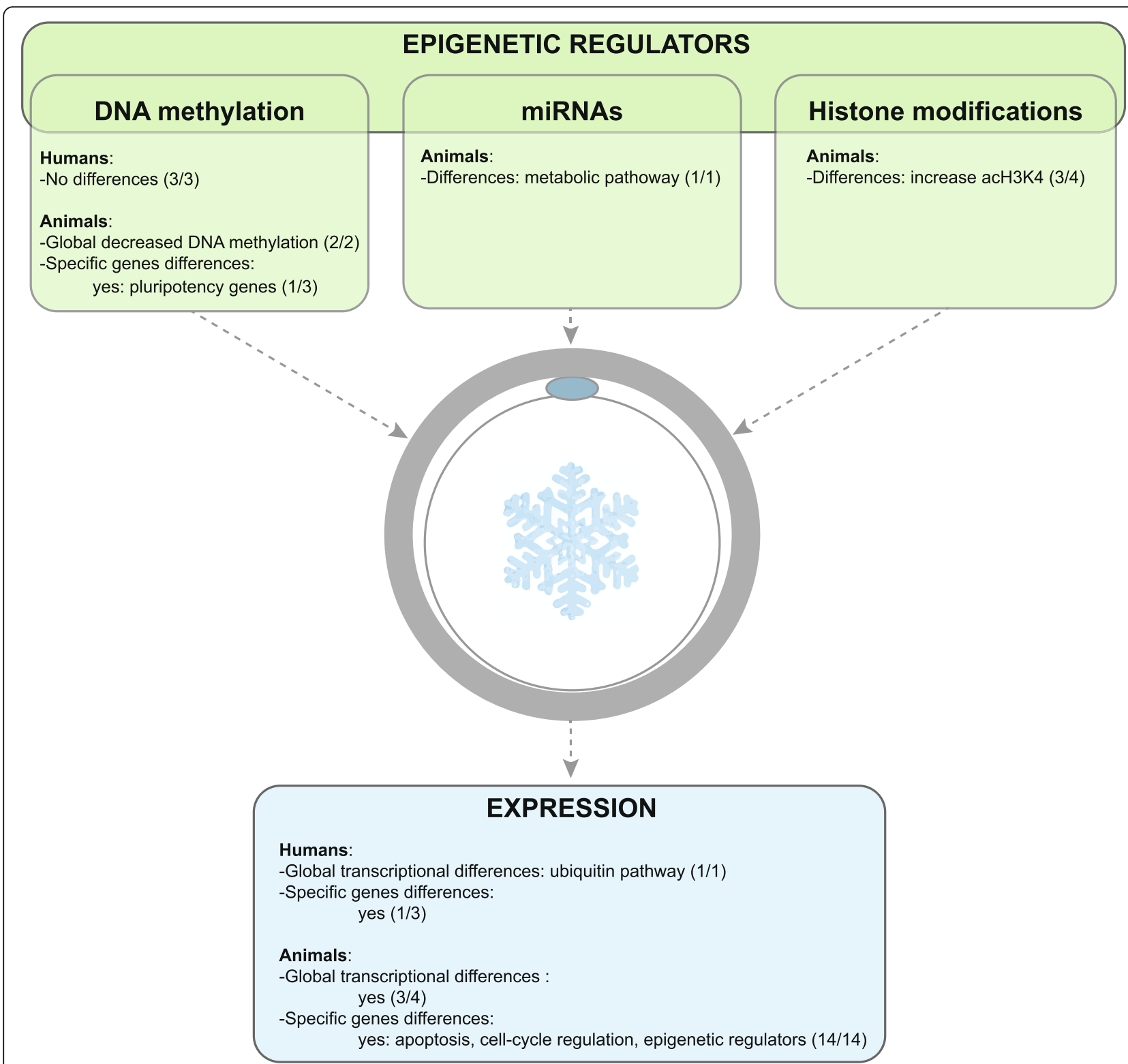

Fig. 2 Epigenetic effects of oocyte vitrification in humans and animals (a global overview). Numbers in brackets mean the number of studies reporting differences out of the total number of studies in the literature

genes. Two of them highlighted that oocyte vitrification did not modify the expression of the selected genes. One analysed the expression of five genes essential for oocyte development and specific functions [124], and the other one focused on the expression of cytokinesis-related genes-Dynactin pathway and subunits [122]. The third human study reported an overall decrease in transcripts involved in DNA structural organization, chromosomal structure maintenance, mitochondrial energetic pathway, cell cycle regulation, and stem cell markers [123].

In summary, the vitrification process may decrease the level of transcripts associated with some of the oocyte's developmental competencies (Fig. 2).
In animals, from diverse models, four studies have used global transcriptomic analyses (i.e. RNA-sequencing) [125-128] (Table 4). In a murine model, Gao et al. found no differences between vitrified and fresh oocytes [125]. On the contrary, differentially expressed genes were found in bovine and porcine oocytes [126-128]. In particular, transcription regulation, cell differentiation and mitosis, regulation of actin cytoskeleton, and apoptosis pathways were found to undergo changes as a result of the oocyte vitrification process.

When the analyses focused specifically on genes involved in epigenetic modifications, a significant downregulation of gene expression after vitrification has been 
Table 2 Impact of oocyte vitrification on DNA methylation and histone modifications in animals

\begin{tabular}{|c|c|c|c|c|c|c|c|}
\hline References & $\begin{array}{l}\text { Animal } \\
\text { model }\end{array}$ & Materials & Number of oocytes & $\begin{array}{l}\text { Number of } \\
\text { embryos }\end{array}$ & $\begin{array}{l}\text { Technology of } \\
\text { assessment }\end{array}$ & $\begin{array}{l}\text { Studied } \\
\text { sequences }\end{array}$ & Conclusions \\
\hline $\begin{array}{l}\text { Chen } \\
\text { et al. [112] }\end{array}$ & Bovine & $\begin{array}{l}\text { Fresh MII, vitrified } \\
\text { MIl or embryos } \\
\text { (D2-D8) from } \\
\text { fresh or vitrified } \\
\text { MIl after IVM }\end{array}$ & $\begin{array}{l}\text { 10-15 oocytes or } \\
\text { embryos per group }\end{array}$ & & Immunofluorescence & $\begin{array}{l}\text { 5mC, } \\
\text { H3K9ac, } \\
\text { H3K9me3 }\end{array}$ & $\begin{array}{l}\text { Decrease in the global DNA } \\
\text { methylation and H3K9me3 levels } \\
\text { and increase in H3K9ac for } \\
\text { vitrified MII oocytes. No } \\
\text { difference observed specifically in } \\
\text { the ICM. Decrease in the level of } \\
\text { DNA methylation and H3K9ac in } \\
\text { trophectoderm after oocyte } \\
\text { vitrification. }\end{array}$ \\
\hline $\begin{array}{l}\text { Cheng } \\
\text { et al. [113] }\end{array}$ & Murine & $\begin{array}{l}\text { Blastocysts (D4) } \\
\text { from fresh or } \\
\text { vitrified MII }\end{array}$ & & $\begin{array}{l}30-45 \\
\text { blastocysts } \\
\text { per } \\
\text { condition }\end{array}$ & $\begin{array}{l}\text { Bisulfite treatment + } \\
\text { sequencing }\end{array}$ & $\begin{array}{l}\text { H19, Peg3, } \\
\text { Snrpn }\end{array}$ & $\begin{array}{l}\text { No significant differences in } \\
\text { oocytes. Decrease in DNA } \\
\text { methylation levels for H19, Peg3, } \\
\text { and Snrpn in blastocysts after } \\
\text { oocyte vitrification. }\end{array}$ \\
\hline $\begin{array}{l}\text { Zhao et al. } \\
\text { [114] }\end{array}$ & Murine & $\begin{array}{l}\text { Fresh MII, vitrified } \\
\text { MII }\end{array}$ & $\begin{array}{l}100 \text { oocytes per } \\
\text { group }\end{array}$ & & $\begin{array}{l}\text { Bisulfite treatment + } \\
\text { sequencing }\end{array}$ & $\begin{array}{l}\text { Dnmt1o, } \\
\text { Hat1, } \\
\text { promoteur } \\
\text { de Hdacl }\end{array}$ & No significant differences. \\
\hline $\begin{array}{l}\text { Hu et al. } \\
\text { [115] }\end{array}$ & Bovine & $\begin{array}{l}\text { Fresh MII after } \\
\text { IVM, vitrified MII } \\
\text { after IVM }\end{array}$ & $\begin{array}{l}150 \text { oocytes per } \\
\text { group }\end{array}$ & & Immunofluorescence & $\begin{array}{l}\text { Global } \\
\text { analysis }\end{array}$ & $\begin{array}{l}\text { Decrease in methylation levels } \\
\text { after oocytes slow freezing or } \\
\text { after use of DMSO. } \\
\text { Increase in methylation levels } \\
\text { after using PROH. }\end{array}$ \\
\hline $\begin{array}{l}\text { Spinaci } \\
\text { et al. [116] }\end{array}$ & Porcine & $\begin{array}{l}\text { Fresh MII after } \\
\text { IVM, vitrified MII } \\
\text { after IVM }\end{array}$ & $\begin{array}{l}\text { H4K5ac } 282 \text { fresh } \\
\text { oocytes, } 192 \text { vitrified } \\
\text { oocytes; H3K9me } 98 \\
\text { fresh oocytes, } 121 \\
\text { vitrified oocytes }\end{array}$ & & Immunofluorescence & $\begin{array}{l}\text { H3K9 } \\
\text { methylation } \\
\text { and H4K5 } \\
\text { acetylation }\end{array}$ & $\begin{array}{l}\text { Increase in H4ac level and } \\
\text { significant modifications of } \\
\text { H3K9me2 levels (decrease or } \\
\text { increase) after oocyte vitrification. }\end{array}$ \\
\hline $\begin{array}{l}\text { Milroy } \\
\text { et al. [117] }\end{array}$ & Murine & $\begin{array}{l}\text { Fresh MII, fresh } \\
\text { MII after IVM, MII } \\
\text { after IVM from } \\
\text { vitrified GV }\end{array}$ & $\begin{array}{l}200 \text { oocytes per } \\
\text { group }\end{array}$ & & $\begin{array}{l}\text { Bisulfite treatment + } \\
\text { sequencing }\end{array}$ & $\begin{array}{l}\text { Pluripotency } \\
\text { promotors } \\
\text { Oct4, Nanog, } \\
\text { Foxd3, Sox2 }\end{array}$ & $\begin{array}{l}\text { Increase in the methylation levels } \\
\text { of Oct4 (25\%) and Sox2 (4.5\%) } \\
\text { promoters after vitrification of } \\
\text { in vitro matured oocytes } \\
\text { compared to in vivo matured } \\
\text { and fresh MII. }\end{array}$ \\
\hline $\begin{array}{l}\text { Yan et al. } \\
\text { [118] }\end{array}$ & Murine & $\begin{array}{l}\text { Fresh MII, vitrified } \\
\text { MII }\end{array}$ & 66 fresh, 70 vitrified & & Immunofluorescence & $\begin{array}{l}\text { H3K9me, } \\
\text { H4K5ac }\end{array}$ & $\begin{array}{l}\text { Increase in the H3K9me and } \\
\text { H4K5ac levels after oocyte } \\
\text { vitrification. }\end{array}$ \\
\hline $\begin{array}{l}\text { Suo et al. } \\
\text { [119] }\end{array}$ & Murine & $\begin{array}{l}\text { Fresh MII, vitrified } \\
\text { MII }\end{array}$ & $\begin{array}{l}\text { At least } 78 \text { oocytes } \\
\text { per group }\end{array}$ & & Immunofluorescence & $\mathrm{H} 4 \mathrm{~K} 12 \mathrm{ac}$ & $\begin{array}{l}\text { Increase in the H4K12ac levels } \\
\text { after oocyte vitrification. } \\
\text { Zygotes from vitrified MII have } \\
\text { disturbed levels before and after } \\
\text { appearance of pronuclei. }\end{array}$ \\
\hline
\end{tabular}

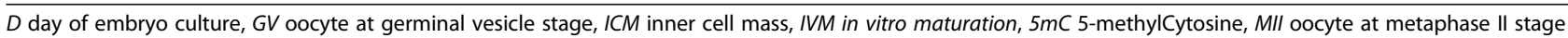

consistently reported (Table 4) [113, 114, 129-131, 133]. However, Chen et al. recently reported an upregulation of two imprinted genes that are known to play a crucial role in development (Gtl2 and Peg10 ) [130].

In bovine and porcine models focused on apoptosis factors, the pro-apoptotic $B A X$ gene expression was mostly upregulated, and the anti-apoptotic $B C L 2$ gene downregulated after the vitrification of mature oocytes [27, 134, 139] (Table 4). However, three studies of cumulo-oocyte complexes found no differences in apoptosis-related gene expression after vitrification warming $[135,137,138]$.

In bovine models, a recent study reported an overexpression of cell division-related gene Eg5 and apoptosisrelated gene $p 53$ [132], while another study described a decreased expression of CD9 after vitrification, potentially resulting in lowered fertilization capacity [136]. In mouse oocytes, vitrification reduces the expression of genes involved in early embryo development (i.e., Mater gene), the positioning of microtubular structures (i.e., Hook1 gene), and spindle assembly checkpoint-related genes (i.e., Mps1 and Mad1 genes) [129, 140]. Similarly in ovine oocytes, decreased expression was reported in a panel of developmentally important genes [141].

\section{Discussion}

In recent years, the quest to improve oocyte cryopreservation protocols has remained central in the field of reproductive medicine, which seeks to provide optimal 
Table 3 Impact of oocyte vitrification on expression in humans

\begin{tabular}{|c|c|c|c|c|c|}
\hline References & Materials & $\begin{array}{l}\text { Number of } \\
\text { oocytes and embryos }\end{array}$ & $\begin{array}{l}\text { Technology } \\
\text { of assessment }\end{array}$ & Studied sequences & Conclusions \\
\hline $\begin{array}{l}\text { D'Aurora } \\
\text { et al. [122] }\end{array}$ & $\begin{array}{l}\text { Supernumerary } \\
\text { MII, fresh or } \\
\text { vitrified }\end{array}$ & 16 fresh, 16 vitrified & RTqPCR & DCTN3, DCTN1, 2, and 6, PLK1 & No significant differences. \\
\hline $\begin{array}{l}\text { Monzo } \\
\text { et al. [121] }\end{array}$ & $\begin{array}{l}\text { Unfertilized MII } \\
(24-78 \mathrm{~h} \text { post- } \\
\text { fertilization), fresh } \\
\text { or vitrified }\end{array}$ & 17 fresh, 36 vitrified & $\begin{array}{l}\text { Microarray } \\
\text { RTqPCR } \\
\text { validation }\end{array}$ & $\begin{array}{l}\text { Global analysis (Affymetrix, HG- } \\
\text { U133 Plus2.0) } \\
3 \text { genes (SLC38a2, TXNRD1, GJA1) }\end{array}$ & $\begin{array}{l}\text { Significant differential expression } \\
\text { between the non-cryopreserved and vit- } \\
\text { rified MII oocyte pools ( } 608 \text { genes with } \\
509 \text { down and } 99 \text { upregulated). Many } \\
\text { genes of the ubiquitination pathway } \\
\text { were downregulated. }\end{array}$ \\
\hline $\begin{array}{l}\text { Chamayou } \\
\text { et al. [123] }\end{array}$ & $\begin{array}{l}\text { Supernumerary } \\
\text { MII, fresh or } \\
\text { vitrified }\end{array}$ & 15 fresh, 15 vitrified & RTqPCR & $\begin{array}{l}\text { NAP1L1, TOP1, H1FOH1, SMC, SCC3, } \\
\text { RAD21, SMC1A, SMC1B, STAG3, } \\
\text { REC8, CLTA, MAPK6, CKS2, DPPA3, } \\
\text { OCT4, FOXJ2 }\end{array}$ & $\begin{array}{l}\text { Overall decrease in the expression after } \\
\text { oocyte vitrification with } 63.3 \% \text { of mRNA } \\
\text { content maintained after vitrification. }\end{array}$ \\
\hline $\begin{array}{l}\text { Di Pietro } \\
\text { et al. [124] }\end{array}$ & $\begin{array}{l}\text { Supernumerary } \\
\text { MIl, fresh or } \\
\text { vitrified }\end{array}$ & 10 fresh, 15 vitrified & RTqPCR & $\begin{array}{l}\text { HPRT, GAPDH, CYCLOPHILIN, } \\
\text { BMP15, GDF9, FIGLA, OCT4, et } \\
\text { TAF4B }\end{array}$ & No significant differences. \\
\hline
\end{tabular}

MII oocyte at metaphase II stage, $R T$-qPCR quantitative reverse transcription $\mathrm{PCR}$

conditions for survival, development, and good clinical outcomes. To date, although vitrification protocols result in relative high survival rates, they do not necessarily signify developmental competence. Previous reports highlighted a decreased cleavage and blastocyst rates after oocyte vitrification in mouse [142, 143], pig [144], cattle [112], and sheep models [141], as well as reduced maturation rates in vitrified immature human oocytes [145]. Additional studies have reported ultrastructural, biochemical, and molecular changes as a result of oocyte vitrification [146].

Very few studies have assessed DNA methylation in humans, which makes it difficult to draw effective conclusions. In addition, the analyses are based either on techniques with low analytical resolution (e.g., IF), or they focused only a few genes subjected to imprinting or specific genes related to cell functions or developmental competences. However, animal studies have shown that oocyte vitrification may (1) modify DNA methylation profiles globally, (2) induce dynamic changes in miRNA content, and (3) cause biochemical changes in histones (high histone acetylation levels).

Epigenetic modifications regulate gene expression so that global DNA demethylation and histone modifications initiate the activation of transcription. Epigenetic changes reported in warmed oocytes could explain the expression changes found in the literature, namely, a global downregulation of expression (in animal models and in humans) $[121,128]$. More particularly, in animal models, the dysregulated genes were found to be involved in epigenetic mechanisms (Dnmt enzymes involved in both de novo and maintenance methylation processes and histone-modifying enzymes), in the cell cycle, and in apoptosis regulation [27, 113, 114, 126$128,134,139]$, while in humans, they were found in the ubiquitination pathway [121]. The inhibition of the machinery degradation through the downregulation of ubiquitination may affect the oocyte proteins content and potentially the developmental abilities.

Now, integrative studies associating transcriptomics and proteomics are needed to decipher the metabolic consequences of these types of expressional modifications.

However, most of the epigenetic and expressional changes were observed from vitrification of immature oocytes (GV stage) followed by in vitro maturation step which is known to decrease subsequent embryo development in several mammals, including humans [127, 133, $147,148]$. Furthermore, the effects of vitrification on epigenetic patterns and expression could vary in a manner dependent on species and gene and may also depend on the genomic regions analysed.

Taken as a whole, the literature suggests that epigenetic and transcriptomic profiles are sensitive to the stress induced by oocyte vitrification. As a consequence of the decreasing amount of the stored maternal RNAs until the genome embryonic activation, potential damage to the biological machinery may contribute to impaired embryonic development potential.

However, there is the remaining crucial question of whether these epigenetic and/or expressional changes have any effect on the long-term fate of vitrified oocytes and subsequent offspring. To date, the reports relative to live birth outcomes after oocyte vitrification are sparse $[19,20,149$, $150]$, and the populations studied are small and poorly or not controlled. The largest study to compare outcomes in vitrified and fresh oocyte groups (including more than one thousand children born after oocyte vitrification) reported reassuring obstetric and perinatal outcomes [19]. However, information regarding the long-term follow-up of these children has not yet been published. 
Table 4 Impact of oocyte vitrification on expression in animals

\begin{tabular}{|c|c|c|c|c|c|c|}
\hline References & $\begin{array}{l}\text { Animal } \\
\text { Model }\end{array}$ & Materials & $\begin{array}{l}\text { Number of } \\
\text { oocytes and } \\
\text { embryos }\end{array}$ & $\begin{array}{l}\text { Technology } \\
\text { of } \\
\text { assessment }\end{array}$ & Studied sequences & Conclusions \\
\hline Wu et al. [129] & Murine & $\begin{array}{l}\mathrm{MI} \text { and MII after IVM } \\
\text { from fresh and } \\
\text { vitrified GV }\end{array}$ & 20-25 per group & RTqPCR & $\begin{array}{l}\text { Mps1, BubR1, Mad1, } \\
\text { Mad2 }\end{array}$ & $\begin{array}{l}\text { Expression of spindle assembly } \\
\text { checkpoint (SAC)-related genes in } \\
\text { GV (Mad1, BubR1, and Mad2), and } \\
\text { MIl stages (Mps1 and Mad1) were } \\
\text { significantly downregulated after } \\
\text { vitrification. }\end{array}$ \\
\hline Chen et al. [130] & Murine & fresh and vitrified MII & 50 per group & RTqPCR & $\begin{array}{l}\text { Gt12, Peg10, Sirt1, Peg3, } \\
\text { Igf2R, H19, Igf2 }\end{array}$ & $\begin{array}{l}\text { Gt } 12 \text { and Peg } 10 \text { were significantly } \\
\text { increased, Peg3, Igf } 2 R \text {, and Sirt } 1 \text { were } \\
\text { significantly decreased after } \\
\text { vitrification }\end{array}$ \\
\hline Jia et al. [127] & Porcine & $\begin{array}{l}\text { MIl after IVM from } \\
\text { vitrified and fresh COC }\end{array}$ & 25 per group & $\begin{array}{l}\text { RNAseq } \\
\text { RTqPCR } \\
\text { validation }\end{array}$ & $\begin{array}{l}\text { Global analysis (Illumina) } \\
21 \text { genes }\end{array}$ & $\begin{array}{l}\text { Significant differential expression } \\
\text { between the non-cryopreserved and } \\
\text { vitrified oocyte pools ( } 19 \text { upregu- } \\
\text { lated genes and } 18 \text { downregulated } \\
\text { after vitrification and IVM). } \\
\text { No GO enrichment or KEGG } \\
\text { pathway was identified. }\end{array}$ \\
\hline $\begin{array}{l}\text { Huang et al. } \\
{[126]}\end{array}$ & Bovine & $\begin{array}{l}\text { GV, MII after IVM from } \\
\text { vitrified GV }\end{array}$ & $\begin{array}{l}3 \text { fresh GV, } 4 \\
\text { vitrified GV, } 1 \\
\text { fresh MII, and } 2 \\
\text { MII derived from } \\
\text { vitrified GV }\end{array}$ & RNAseq & Global analysis (Illumina) & $\begin{array}{l}\text { For GV, } 12 \text { upregulated genes and } \\
19 \text { downregulated genes after } \\
\text { vitrification. No GO enrichment or } \\
\text { KEGG pathway was identified. } \\
\text { For MII, } 47 \text { upregulated genes and } 6 \\
\text { downregulated genes after } \\
\text { vitrification. With GO and KEGG } \\
\text { analyses, several pathways were } \\
\text { identified: transcription regulation, } \\
\text { cell differentiation and mitosis, } \\
\text { regulation of actin cytoskeleton, and } \\
\text { apoptosis. }\end{array}$ \\
\hline
\end{tabular}

Ma et al. [131] Bovine MIl after IVM from fresh GV, MII after IVM from vitrified $\mathrm{GV}$, fresh GV, vitrified GV

Gao et al. [125] Murine MIl after IVM from fresh GV, MII after IVM from vitrified GV, fresh MII, vitrified MII

Wu et al. [132] Bovine MIl after IVM from vitrified GV (liquid nitrogen-LN or helium-LHe), MII after IVM from fresh GV

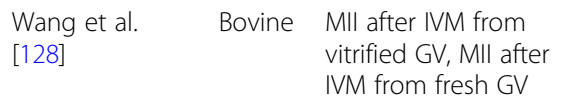

20 per group

RNAseq RTqPCR validation

15 per group $(* 3 \quad$ RTqPCR experiments)

100 per group

RNAseq

RTqPCR validation

CD9, CD81, DNMT1, and DNMT36

$$
\text { apoptosis. }
$$

$$
\begin{array}{ll}
120 \text { per group } \quad \text { RTqPCR } & \text { p53, EG5, CDC20, and } \\
\text { NPM2 }
\end{array}
$$

Global analysis (Illumina) Atp5e, Atp5o, Ndufb9, Uqcrq, Timm17a, Dppa5a, H3f3a, Timm13, and Tomm 40

Global analysis (Illumina) CDK2, UCHL3, CALM, VDAC2, DPH6, MED27, DAD1, MED21, NR1H4, and HMGN1

RTqPCR

STAT3, HAT1, HDAC1, SUV39H1, DNMT1, HMGN3a, SMARCAL1, and DNMT3b

Zhao et al. [27] Bovine MIl after IVM from vitrified GV, MII after IVM from fresh GV
100 per group RTgPCR BAX and BCL2/11
The expression of all analysed genes was downregulated after IVM of vitrified GV when compared to the fresh in vitro matured MII oocytes.

No effect of vitrification on the transcriptome. Differences were reported for IVM.

For LN-effet, p53 and EG5 were upregulated after vitrification, and CDC20 was downregulated. For LHe-effect, lower effect on the expression of some related genes compared to LN vitrification.

Significant differential expression between the non-cryopreserved and vitrified oocyte pools (12 upregulated genes and 90 downregulated genes). At GO analysis, several enrichments in terms of membranebounded organelles, macromolecular complex, and intra-cellular part were found. No KEGG pathway was identified.

The HMG3a and HDAC1 expression was downregulated after vitrification.

The $B A X$ expression was upregulated and the BCL2 I1 expression was downregulated after vitrification. 
Table 4 Impact of oocyte vitrification on expression in animals (Continued)

\begin{tabular}{|c|c|c|c|c|c|c|}
\hline References & $\begin{array}{l}\text { Animal } \\
\text { Model }\end{array}$ & Materials & $\begin{array}{l}\text { Number of } \\
\text { oocytes and } \\
\text { embryos }\end{array}$ & $\begin{array}{l}\text { Technology } \\
\text { of } \\
\text { assessment }\end{array}$ & Studied sequences & Conclusions \\
\hline Dai et al. [134] & Porcine & Fresh MII, vitrified MII & 100 per group & RTqPCR & $\begin{array}{l}\text { DNM1, SOD1, MFN2, BAX, } \\
\text { and } B C L 2\end{array}$ & $\begin{array}{l}\text { The DNM1 expression was } \\
\text { upregulated, and the } S O D 1, M F N 2 \text {, } \\
B A X \text {, and } B C L 2 \text { were downregulated } \\
\text { after vitrification. }\end{array}$ \\
\hline $\begin{array}{l}\text { Spricigo et al. } \\
\text { [135] }\end{array}$ & Bovine & $\begin{array}{l}\text { MII after IVM from } \\
\text { vitrified COC, MII after } \\
\text { IVM from fresh COC }\end{array}$ & $\begin{array}{l}20 \text { per group }(* 4 \\
\text { experiments) }\end{array}$ & RTqPCR & $\begin{array}{l}\text { DNMT1, SUV39H1, } \\
\text { HDAC2, TP53, and CASP3 }\end{array}$ & No effect of vitrification. \\
\hline $\begin{array}{l}\text { Cheng et al. } \\
\text { [113] }\end{array}$ & Murine & Fresh MII, vitrified MII & 100 per group & RTqPCR & Dnmt1,3a,3b,3l & $\begin{array}{l}\text { The DNMTs expression was } \\
\text { significantly reduced after } \\
\text { vitrification. }\end{array}$ \\
\hline Zhao et al. [114] & Murine & Fresh MII, vitrified MII & 200 per group & RTqPCR & $\begin{array}{l}\text { Dnmt10, Hat1, and } \\
\text { Hdac1 promoters }\end{array}$ & $\begin{array}{l}\text { No effect of vitrification on the } \\
\text { mRNA expression levels of Hat } 1 \text { and } \\
\text { Hdac1. } \\
\text { The Dnmt1o expression was } \\
\text { significantly reduced after } \\
\text { vitrification. }\end{array}$ \\
\hline Zhou et al. [136] & Bovine & Fresh MII, vitrified MII & 50 per group & RTqPCR & CD9 & $\begin{array}{l}\text { The CD9 expression was } \\
\text { downregulated after vitrification. }\end{array}$ \\
\hline Rao et al. [137] & Caprine & $\begin{array}{l}\text { MIl after IVM from } \\
\text { vitrified and fresh COC }\end{array}$ & 60 per group & RTqPCR & $\begin{array}{l}\text { GDF9, BMP15, TGFBR1, } \\
\text { BPR2, BCL2, BAX and P53 }\end{array}$ & $\begin{array}{l}\text { No significant differences of most of } \\
\text { the genes. }\end{array}$ \\
\hline $\begin{array}{l}\text { Turathum et al. } \\
\text { [138] }\end{array}$ & Canine & $\begin{array}{l}\text { MIl after IVM from } \\
\text { vitrified and fresh COC }\end{array}$ & $\begin{array}{l}200 \text { vitrified, } 292 \\
\text { fresh }\end{array}$ & RTqPCR & $\begin{array}{l}\text { HSP70, Dnmt1, SOD1, } \\
B A X \text {, and } B C 12\end{array}$ & $\begin{array}{l}\text { BCl2 expression was increased after } \\
\text { vitrification, whereas BAX was not } \\
\text { expressed in both groups. }\end{array}$ \\
\hline $\begin{array}{l}\text { Anchamparuthy } \\
\text { et al. [139] }\end{array}$ & Bovine & $\begin{array}{l}\text { Fresh GV, MII after IVM } \\
\text { from vitrified GV, MII } \\
\text { after IVM from fresh } \\
\text { GV }\end{array}$ & 25 per group & RT-qPCR & $\begin{array}{l}18 S \text { rRNA, Fas, FasL, Bax, } \\
\text { and Bcl-2 }\end{array}$ & $\begin{array}{l}\text { The Bax expression was upregulated } \\
\text { after vitrification with the ratio of } \\
\text { Bax:Bcl-2 elevated. }\end{array}$ \\
\hline $\begin{array}{l}\text { Habibi et al. } \\
{[140]}\end{array}$ & Murine & $\begin{array}{l}\text { MII after IVM from } \\
\text { vitrified GV, MII after } \\
\text { IVM from fresh GV }\end{array}$ & $\begin{array}{l}10 \text { per group (*3 } \\
\text { experiments) }\end{array}$ & RT-qPCR & Mater, Sod1, and Hook1 & $\begin{array}{l}\text { The Mater and Hook1 expression } \\
\text { was downregulated after } \\
\text { vitrification. }\end{array}$ \\
\hline $\begin{array}{l}\text { Succu et al. } \\
{[141]}\end{array}$ & Ovine & $\begin{array}{l}\text { MII after IVM from } \\
\text { vitrified GV, MII after } \\
\text { IVM from fresh GV }\end{array}$ & $\begin{array}{l}40 \text { vitrified, } 24 \\
\text { fresh }\end{array}$ & RT-qPCR & $\begin{array}{l}\text { b-actin, H2A.Z histone, } \\
\text { Poli A, PAP, HSP90b, } \\
\text { P34Cdc2, Cyclin B, Na/K- } \\
\text { ATPase and Type I } \\
\text { cadherin }\end{array}$ & $\begin{array}{l}\text { Except for the } b \text {-actin and } H 2 A . Z \\
\text { expression, all gene expression was } \\
\text { downregulated after vitrification. }\end{array}$ \\
\hline
\end{tabular}

GV oocyte at germinal vesicle stage, IVM in vitro maturation, KEGG Kyoto Encyclopedia of Genes and Genomes, LN liquid nitrogen; LHe = liquid helium, MII oocyte at metaphase II stage, GO gene ontology, RNAseq RNA sequencing, RT-qPCR quantitative reverse transcription PCR

\section{Conclusion}

This literature review highlights that there is a need to learn more about the regulatory mechanisms potentially affected by the oocyte vitrification-warming process, particularly in humans. In addition, despite the overwhelming number of transposable elements, their importance in gametogenesis and development, and their ability to alter genome function, research on the expression of TEs is totally lacking in the field of ART. However, current investigations are facilitated by new technologies that are able to perform a large-scale analysis of DNA methylation (methylome) and transcription (transcriptome) from a small amount of material (as little as a single cell). Finally, the effect of cryo-variables (e.g., type and concentration of cryoprotectors) on epigenetic status and their possible biological implications need to be more fully assessed in order to improve the safety and efficacy of cryopreservation for its diverse applications.

\section{Abbreviations}

ART: Assisted reproductive technologies; COC: Cumulus-oocyte complex; CpG: Cytosine-guanine dinucleotide; CGI: CpG island; D: Day of embryo culture; DMRs: Differentially methylated regions; DNMTs: DNA methyl transferases; GO: Gene Ontology; GV: Oocyte at germinal vesicle stage; ICM: Inner cell mass; ICRs: Imprinting control regions;

IF: Immunofluorescence; IVM: In vitro maturation; KEGG: Kyoto Encyclopedia of Genes and Genomes; LN: Liquid nitrogen; LHe: Liquid helium; MI: Oocyte at metaphase I stage; MII: Oocyte at metaphase II stage; 5mC: 5MethylCytosine; 5hmC: 5-HydroxymethylCytosine; miRNAs: MicroRNAs; PGC: Primordial germ cells; RNAseq: RNA sequencing; RT-qPCR: Quantitative reverse transcription PCR; TE: Transposable element

\section{Acknowledgements}

The authors thank the clinical and technical teams of the IVF Center of Dijon for their collaboration. We thank Suzanne Rankin for proofreading the manuscript.

\section{Authors' contributions}

$J B$ and $C B$ undertook the initial systematic search and screening of the literature. JB and PF summarised the findings from articles. $F B, C B, C C, M G$, and RS oversaw additional input and revisions to manuscript drafts. PF and 
JB drafted the manuscript. All authors read and approved the final manuscript.

\section{Funding}

The Fauque's research is supported by the Research National Agency "Agence Nationale pour la Recherche" (ANR-17-CE12-0014), AOI (2017 InstruVIT), ABM (2020)

\section{Availability of data and materials \\ Not applicable}

\section{Ethics approval and consent to participate}

Not applicable

\section{Consent for publication}

Not applicable

\section{Competing interests}

The authors declare that they have no competing interests.

\section{Author details}

${ }^{1} \mathrm{CHU}$ Dijon Bourgogne, Laboratoire de Biologie de la Reproduction, CECOS, 14 rue Gaffarel, 21079 Dijon Cedex, France. ${ }^{2}$ Gynécologie-Obstétrique, CHU Dijon Bourgogne, 14 rue Gaffarel, 21079 Dijon Cedex, France.

\section{Received: 13 March 2020 Accepted: 21 July 2020}

Published online: 10 August 2020

\section{References}

1. European IVFmC, European Society of Human R, Embryology, Calhaz-Jorge C, De Geyter C, Kupka MS, et al. Hum Reprod. 2017;32:1957-73.

2. De Geyter C, Calhaz-Jorge C, Kupka MS, Wyns C, Mocanu E, Motrenko T, et al. Art in Europe, 2014: results generated from European registries by Eshre: the European Ivf-monitoring consortium (Eim) for the European Society of Human Reproduction and Embryology (Eshre). Hum Reprod. 2018:33:1586-601.

3. Hart R, Norman RJ. The longer-term health outcomes for children born as a result of Ivf treatment: part I--general health outcomes. Hum Reprod Update. 2013;19:232-43.

4. Vermeiden JP, Bernardus RE. Are imprinting disorders more prevalent after juman in vitro fertilization or intracytoplasmic sperm injection? Fertil Steril. 2013;99:642-51.

5. Vrooman LA, Bartolomei MS. Can assisted reproductive technologies cause adult-onset disease? Evidence from human and mouse. Reprod Toxicol. 2017;68:72-84.

6. Guo H, Zhu P, Yan L, Li R, Hu B, Lian Y, et al. The DNA methylation landscape of human early embryos. Nature. 2014;511:606-10.

7. Smith ZD, Chan MM, Humm KC, Karnik R, Mekhoubad S, Regev A, et al. DNA methylation dynamics of the human preimplantation embryo. Nature. 2014;511:611-5.

8. Chen C. Pregnancy after human oocyte cryopreservation. Lancet. 1986;1: 884-6.

9. Boldt J, Tidswell N, Sayers A, Kilani R, Cline D. Human oocyte cryopreservation: 5 -year experience with a sodium-depleted slow freezing method. Reprod BioMed Online. 2006;13:96-100.

10. Cai LB, Qian XQ, Wang W, Mao YD, Yan ZJ, Liu CZ, et al. Oocyte vitrification technology has made egg-sharing donation easier in China. Reprod BioMed Online. 2012;24:186-90.

11. Cobo A, Kuwayama M, Perez S, Ruiz A, Pellicer A, Remohi J. Comparison of concomitant outcome achieved with fresh and cryopreserved donor oocytes vitrified by the cryotop method. Fertil Steril. 2008;89:1657-64.

12. Oktay K, Oktem O. Ovarian cryopreservation and transplantation for fertility preservation for medical indications: report of an ongoing experience. Fertil Steril. 2010;93:762-8

13. Parmegiani L, Cognigni GE, Bernardi S, Cuomo S, Ciampaglia W, Infante FE, et al. Efficiency of aseptic open vitrification and hermetical cryostorage of human oocytes. Reprod BioMed Online. 2011;23:505-12.

14. Potdar N, Gelbaya TA, Nardo LG. Oocyte vitrification in the 21 st century and post-warming fertility outcomes: a systematic review and meta-analysis. Reprod BioMed Online. 2014;29:159-76.
15. Rienzi L, Cobo A, Paffoni A, Scarduelli C, Capalbo A, Vajta G, et al. Consistent and predictable delivery rates after oocyte vitrification: an observational longitudinal cohort multicentric study. Hum Reprod. 2012;27:1606-12.

16. Sole M, Santalo J, Boada M, Clua E, Rodriguez I, Martinez F, et al. How does vitrification affect oocyte viability in oocyte donation cycles? A prospective study to compare outcomes achieved with fresh versus vitrified sibling oocytes. Hum Reprod. 2013;28:2087-92.

17. Trokoudes KM, Pavlides C, Zhang X. Comparison outcome of fresh and vitrified donor oocytes in an egg-sharing donation program. Fertil Steril. 2011:95:1996-2000.

18. Rienzi L, Gracia C, Maggiulli R, LaBarbera AR, Kaser DJ, Ubaldi FM, et al. Oocyte, embryo and blastocyst cryopreservation in art: systematic review and meta-analysis comparing slow-freezing versus vitrification to produce evidence for the development of global guidance. Hum Reprod Update. 2017:23:139-55.

19. Cobo A, Serra V, Garrido N, Olmo I, Pellicer A, Remohi J. Obstetric and perinatal outcome of babies born from vitrified oocytes. Fertil Steril. 2014; 102:1006-15 e4.

20. Martinez M, Rabadan S, Domingo J, Cobo A, Pellicer A, Garcia-Velasco JA. Obstetric outcome after oocyte vitrification and warming for fertility preservation in women with cancer. Reprod BioMed Online. 2014:29:722-8.

21. Oktay K, Cil AP, Bang H. Efficiency of oocyte cryopreservation: a metaanalysis. Fertil Steril. 2006;86:70-80.

22. Cobo A, Garcia-Velasco JA, Coello A, Domingo J, Pellicer A, Remohi J. Oocyte Vitrification as an efficient option for elective fertility preservation. Fertil Steril. 2016;105:755-64 e8.

23. Cobo A, Diaz C. Clinical application of oocyte vitrification: a systematic review and meta-analysis of randomized controlled trials. Fertil Steril. 2011; 96:277-85.

24. Dolmans MM, Manavella DD. Recent advances in fertility preservation. J Obstetrics Gynaecol Res. 2019;45:266-79.

25. Kohaya N, Fujiwara K, Ito J, Kashiwazaki N. Generation of live offspring from vitrified mouse oocytes of C57bl/6j strain. PLoS One. 2013;8:e58063.

26. Phongnimitr $T$, Liang $Y$, Srirattana $K$, Panyawai $K$, Sripunya N, Treetampinich $\mathrm{C}$, et al. Effect of L-carnitine on maturation, cryo-tolerance and embryo developmental competence of bovine oocytes. Anim Sci J. 2013;84:719-25.

27. Zhao XM, Hao HS, Du WH, Zhao SJ, Wang HY, Wang N, et al. Melatonin inhibits apoptosis and improves the developmental potential of vitrified bovine oocytes. J Pineal Res. 2016;60:132-41.

28. Christou-Kent M, Dhellemmes M, Lambert E, Ray PF, Arnoult C. Diversity of Rna-binding proteins modulating post-transcriptional regulation of protein expression in the maturing mammalian oocyte. Cells. 2020;9.

29. Sendzikaite $G$, Kelsey $G$. The role and mechanisms of DNA methylation in the oocyte. Essays Biochem. 2019;63:691-705.

30. Reyes JM, Ross PJ. Cytoplasmic polyadenylation in mammalian oocyte maturation. Wiley Interdiscip Rev RNA. 2016;7:71-89.

31. Conti M, Franciosi F. Acquisition of oocyte competence to develop as an embryo: integrated nuclear and cytoplasmic events. Hum Reprod Update. 2018:24:245-66.

32. Albertini DF, Olsen R. Effects of fertility preservation on oocyte genomic integrity. Adv Exp Med Biol. 2013;761:19-27.

33. Ito S, Shen L, Dai Q, Wu SC, Collins LB, Swenberg JA et al. Tet proteins can convert 5-methylcytosine to 5-formylcytosine and 5-carboxylcytosine. Science. 2011;333:1300-3

34. Tahiliani M, Koh KP, Shen Y, Pastor WA, Bandukwala H, Brudno Y, et al. Conversion of 5-methylcytosine to 5-hydroxymethylcytosine in mammalian DNA by MII partner Tet1. Science. 2009:324:930-5.

35. Rose NR, Klose RJ. Understanding the relationship between DNA methylation and histone lysine methylation. Biochim Biophys Acta. 1839: 2014:1362-72.

36. http://Www.Mousebook.Org/Mousebook-Catalogs/ImprintingResource?Catalog=Imprinting. MouseBook Imprinting Catalog..

37. http://lgc.Otago.Ac.Nz/Home.html. Catalogue of Parent of Origin Effects.

38. Fauque $P$, Bourc'his $D$. Genes are not the whole story: retrotransposons as new determinants of male fertility. Textbook of Human Reproductive Genetics, vol Cambridge medicine. Cambridge University Press; 2014.

39. Zamudio N, Barau J, Teissandier A, Walter M, Borsos M, Servant N, et al. DNA methylation restrains transposons from adopting a chromatin signature permissive for meiotic recombination. Genes Dev. 2015;29:1256-70.

40. Burns KH, Boeke JD. Human transposon tectonics. Cell. 2012;149:740-52. 
41. Waterston RH, Lander ES, Sulston JE. On the sequencing of the human genome. Proc Natl Acad Sci U S A. 2002;99:3712-6.

42. Grow EJ, Flynn RA, Chavez SL, Bayless NL, Wossidlo M, Wesche DJ, et al. Intrinsic retroviral reactivation in human preimplantation embryos and pluripotent cells. Nature. 2015;522:221-5.

43. Friedli M, Trono D. The developmental control of transposable elements and the evolution of higher species. Ann Rev Cell Dev Biol. 2015;31:429-51.

44. Zamudio N, Bourc'his D. Transposable elements in the mammalian germline: a comfortable niche or a deadly trap? Heredity (Edinb). 2010;105 92-104.

45. Goodier JL, Kazazian HH Jr. Retrotransposons revisited: the restraint and rehabilitation of parasites. Cell. 2008;135:23-35.

46. Malki S, van der Heijden GW, O'Donnell KA, Martin SL, Bortvin A. A role for retrotransposon line-1 in fetal oocyte attrition in mice. Dev Cell. 2014;29: 521-33.

47. Kazazian HH Jr, Moran JV. Mobile DNA in health and disease. N Engl J Med. 2017:377:361-70.

48. Veselovska L, Smallwood SA, Saadeh H, Stewart KR, Krueger F, MaupetitMehouas $S$, et al. Deep sequencing and de novo assembly of the mouse oocyte transcriptome define the contribution of transcription to the DNA methylation landscape. Genome Biol. 2015;16:209.

49. Peaston AE, Evsikov AV, Graber JH, de Vries WN, Holbrook AE, Solter D, et al. Retrotransposons regulate host genes in mouse oocytes and preimplantation embryos. Dev Cell. 2004;7:597-606.

50. Franke V, Ganesh S, Karlic R, Malik R, Pasulka J, Horvat F, et al. Long terminal repeats power evolution of genes and gene expression programs in mammalian oocytes and zygotes. Genome Res. 2017;27:1384-94.

51. Li E, Zhang Y. DNA methylation in mammals. Cold Spring Harb Perspect Biol. 2014;6:a019133.

52. Lowdon RF, Jang HS, Wang T. Evolution of epigenetic regulation in vertebrate genomes. Trends Genet. 2016;32:269-83.

53. Illingworth RS, Bird AP. Cpg Islands--'a rough Guide'. FEBS Lett. 2009;583: 1713-20.

54. Straussman R, Nejman D, Roberts D, Steinfeld I, Blum B, Benvenisty N, et al. Developmental programming of Cpg island methylation profiles in the human genome. Nat Struct Mol Biol. 2009;16:564-71.

55. Gujar H, Weisenberger DJ, Liang G, et al. Genes (Basel). 2019;10.

56. Bogdanovic $\mathrm{O}$, Smits AH, de la Calle ME, Tena JJ, Ford E, Williams R, et al. Active DNA demethylation at enhancers during the vertebrate phylotypic period. Nat Genet. 2016:48:417-26.

57. Jones PA. Functions of DNA methylation: islands, start sites, gene bodies and beyond. Nat Rev Genet. 2012;13:484-92.

58. Greenberg MVC, Bourc'his D. The diverse roles of DNA methylation in mammalian development and disease. Nat Rev Mol Cell Biol. 2019;20:590-607.

59. Smallwood SA, Tomizawa S, Krueger F, Ruf N, Carli N, Segonds-Pichon A, et al. Dynamic Cpg island methylation landscape in oocytes and preimplantation embryos. Nat Genet. 2011;43:811-4.

60. Rutledge CE, Thakur A, O'Neill KM, Irwin RE, Sato S, Hata K, et al. Ontogeny, conservation and functional significance of maternally inherited DNA methylation at two classes of non-imprinted genes. Development. 2014;141: 1313-23.

61. Guo F, Yan L, Guo H, Li L, Hu B, Zhao Y, et al. The transcriptome and DNA methylome landscapes of human primordial germ cells. Cell. 2015;161: 1437-52.

62. von Meyenn F, Reik W. Forget the parents: epigenetic reprogramming in human germ cells. Cell. 2015;161:1248-51.

63. Cantone I, Fisher AG. Epigenetic programming and reprogramming during development. Nat Struct Mol Biol. 2013;20:282-9.

64. Saitou M, Kagiwada S, Kurimoto K. Epigenetic reprogramming in mouse pre-implantation development and primordial germ cells. Development. 2012;139:15-31.

65. Smallwood SA, Kelsey G. De novo DNA methylation: a germ cell perspective. Trends Genet. 2012;28:33-42.

66. Bourc'his D, Xu GL, Lin CS, Bollman B, Bestor TH. Dnmt3l and the establishment of maternal genomic imprints. Science. 2001;294:2536-9.

67. Kaneda M, Okano M, Hata K, Sado T, Tsujimoto N, Li E, et al. Essential role for de novo DNA methyltransferase Dnmt3a in paternal and maternal imprinting. Nature. 2004;429:900-3.

68. Fauque P. Ovulation induction and epigenetic anomalies. Fertil Steril. 2013 99:616-23.
69. Fauque $P$, Jouannet $P$, Jammes $H$. Parental imprinting related to assisted reproductive technologies. Gynecol Obstet Fertil. 2008;36:1139-46.

70. Reik W, Surani MA. Germline and pluripotent stem cells. Cold Spring Harb Perspect Biol. 2015;7.

71. Barlow DP, Bartolomei MS. Genomic imprinting in mammals. Cold Spring Harb Perspect Biol. 2014;6.

72. Li X, Ito M, Zhou F, Youngson N, Zuo X, Leder P, et al. A maternal-zygotic effect gene, Zfp57, maintains both maternal and paternal imprints. Dev Cell. 2008;15:547-57.

73. Quenneville S, Verde G, Corsinotti A, Kapopoulou A, Jakobsson J, Offner S, et al. In embryonic stem cells, Zfp57/Kap1 recognize a methylated hexanucleotide to affect chromatin and DNA methylation of imprinting control r-egions. Mol Cell. 2011;44:361-72.

74. Uysal F, Akkoyunlu G, Ozturk S. Dynamic expression of DNA methyltransferases (Dnmts) in oocytes and early embryos. Biochimie. 2015; 116:103-13

75. Howell CY, Bestor TH, Ding F, Latham KE, Mertineit C, Trasler JM, et al. Genomic imprinting disrupted by a maternal effect mutation in the Dnmt1 gene. Cell. 2001;104:829-38.

76. Cirio MC, Martel J, Mann M, Toppings M, Bartolomei M, Trasler J, et al. DNA methyltransferase 10 functions during preimplantation development to preclude a profound level of epigenetic variation. Dev Biol. 2008;324:139-50.

77. Petrussa L, Van de Velde H, De Rycke M. Dynamic regulation of DNA methyltransferases in human oocytes and preimplantation embryos after assisted reproductive technologies. Mol Hum Reprod. 2014;20:861-74.

78. Brind'Amour J, Kobayashi H, Richard Albert J, Shirane K, Sakashita A, Kamio A, et al. Ltr retrotransposons transcribed in oocytes drive species-specific and heritable changes in DNA methylation. Nat Commun. 2018;9:3331.

79. Kobayashi H, Sakurai T, Imai M, Takahashi N, Fukuda A, Yayoi O, et al. Contribution of intragenic DNA methylation in mouse gametic DNA methylomes to establish oocyte-specific heritable marks. PLoS Genet. 2012; 8:e1002440.

80. Peterson CL, Laniel MA. Histones and histone modifications. Curr Biol. 2004; 14:R546-51.

81. Kouzarides T. Snapshot: histone-modifying enzymes. Cell. 2007;131:822.

82. Clarke HJ, Vieux KF. Epigenetic inheritance through the female germ-line: the known, the unknown, and the possible. Semin Cell Dev Biol. 2015;43: 106-16.

83. Beaujean N. Histone post-translational modifications in preimplantation mouse embryos and their role in nuclear architecture. Mol Reprod Dev. 2014;81:100-12.

84. Xu Q, Xie W. Epigenome in early mammalian development: inheritance, reprogramming and establishment. Trends Cell Biol. 2018;28:237-53.

85. Hammoud SS, Nix DA, Zhang H, Purwar J, Carrell DT, Cairns BR. Distinctive chromatin in human sperm packages genes for embryo development. Nature. 2009;460:473-8.

86. Santos F, Hendrich B, Reik W, Dean W. Dynamic reprogramming of DNA methylation in the early mouse embryo. Dev Biol. 2002;241:172-82.

87. Burton A, Torres-Padilla ME. Epigenetic reprogramming and development: a unique heterochromatin organization in the preimplantation mouse embryo. Brief Funct Genomics. 2010;9:444-54.

88. Zhang B, Zheng H, Huang B, Li W, Xiang Y, Peng X, et al. Allelic reprogramming of the histone modification $\mathrm{H} 3 \mathrm{k} 4 \mathrm{me} 3$ in early mammalian development. Nature. 2016:537:553-7.

89. Dahl JA, Jung I, Aanes H, Greggains GD, Manaf A, Lerdrup M, et al. Broad histone $\mathrm{H} 3 \mathrm{k} 4 \mathrm{me} 3$ domains in mouse oocytes modulate maternal-to-zygotic transition. Nature. 2016;537:548-52.

90. Zheng H, Huang B, Zhang B, Xiang Y, Du Z, Xu Q, et al. Resetting epigenetic memory by reprogramming of histone modifications in mammals. Mol Cell. 2016;63:1066-79.

91. Rangasamy D. Distinctive patterns of epigenetic marks are associated with promoter regions of mouse line-1 and Ltr retrotransposons. Mob DNA. 2013;4:27.

92. Qureshi IA, Mehler MF. Emerging roles of non-coding Rnas in brain evolution, development, plasticity and disease. Nat Rev Neurosci. 2012;13: 528-41.

93. Esteller M. Non-coding Rnas in human disease. Nat Rev Genet. 2011;12:861-74.

94. Quinn JJ, Chang HY. Unique features of long non-coding Rna biogenesis and function. Nat Rev Genet. 2016;17:47-62.

95. Payer B. Developmental regulation of X-chromosome inactivation. Semin Cell Dev Biol. 2016;56:88-99. 
96. Svoboda P. Long and small noncoding Rnas during oocyte-to-embryo transition in mammals. Biochem Soc Trans. 2017;45:1117-24.

97. Ganesh S, Svoboda P. Retrotransposon-associated long non-coding Rnas in mice and men. Pflugers Arch. 2016:468:1049-60.

98. O'Brien J, Hayder H, Zayed Y, Peng C. Overview of microrna biogenesis, mechanisms of actions, and circulation. Front Endocrinol (Lausanne). 2018:9:402

99. Suh N, Blelloch R. Small Rnas in early mammalian development: from gametes to gastrulation. Development. 2011;138:1653-61.

100. Hossain MM, Salilew-Wondim D, Schellander K, Tesfaye D. The role of micrornas in mammalian oocytes and embryos. Anim Reprod Sci. 2012;134: 36-44.

101. Salas-Huetos A, James ER, Aston KI, Jenkins TG, Carrell DT, Yeste M. The expression of mirnas in human ovaries, oocytes, extracellular vesicles, and early embryos: a systematic review. Cells. 2019;8.

102. Hilz S, Modzelewski AJ, Cohen PE, Grimson A. The roles of micrornas and sirnas in mammalian spermatogenesis. Development. 2016;143:3061-73.

103. Watanabe T, Totoki $Y$, Toyoda A, Kaneda M, Kuramochi-Miyagawa S, Obata $Y$, et al. Endogenous sirnas from naturally formed Dsrnas regulate transcripts in mouse oocytes. Nature. 2008;453:539-43.

104. Tam OH, Aravin AA, Stein P, Girard A, Murchison EP, Cheloufi S, et al. Pseudogene-derived small interfering Rnas regulate gene expression in mouse oocytes. Nature. 2008;453:534-8.

105. Yang F, Wang PJ. Multiple lines of retrotransposon silencing mechanisms in the mammalian germline. Semin Cell Dev Biol. 2016;59:118-25.

106. Stein P, Rozhkov NV, Li F, Cardenas FL, Davydenko O, Vandivier LE, et al. Essential role for endogenous sirnas during meiosis in mouse oocytes. PLoS Genet. 2015;11:e1005013.

107. Yang Q, Li R, Lyu Q, Hou L, Liu Z, Sun Q, et al. Single-cell Cas-Seq reveals a class of short piwi-interacting Rnas in human oocytes. Nat Commun. 2019; 10:3389.

108. Malki S, van der Heijden GW, O'Donnell KA, Martin SL, Bortvin A. A role for retrotransposon line-1 in fetal oocyte attrition in mice. Dev Cell. 2019;51:658.

109. Liu MH, Zhou WH, Chu DP, Fu L, Sha W, Li Y. Ultrastructural changes and methylation of human oocytes vitrified at the germinal vesicle stage and matured in vitro after thawing. Gynecol Obstetric Invest. 2017:82:252-61.

110. De Munck N, Petrussa L, Verheyen G, Staessen C, Vandeskelde Y, Sterckx J, et al. Chromosomal meiotic segregation, embryonic developmental kinetics and DNA (hydroxy)methylation analysis consolidate the safety of human oocyte vitrification. Mol Hum Reprod. 2015;21:535-44.

111. Al-Khtib M, Perret A, Khoueiry R, Ibala-Romdhane S, Blachere T, Greze C, et al. Vitrification at the germinal vesicle stage does not affect the methylation profile of $\mathrm{H} 19$ and Kcnq1ot1 imprinting centers in human oocytes subsequently matured in vitro. Fertil Steril. 2011;95:1955-60.

112. Chen H, Zhang L, Deng T, Zou P, Wang Y, Quan F, et al. Effects of oocyte vitrification on epigenetic status in early bovine embryos. Theriogenology. 2016:86:868-78.

113. Cheng KR, Fu XW, Zhang RN, Jia GX, Hou YP, Zhu SE. Effect of oocyte vitrification on deoxyribonucleic acid methylation of H19, Peg3, and Snrpn differentially methylated regions in mouse blastocysts. Fertil Steril. 2014;102: 1183-90 e3

114. Zhao XM, Ren JJ, Du WH, Hao HS, Wang D, Qin T, et al. Effect of vitrification on promoter Cpg island methylation patterns and expression levels of DNA methyltransferase 10, histone acetyltransferase 1, and deacetylase 1 in metaphase li mouse oocytes. Fertil Steril. 2013;100:256-61.

115. Hu W, Marchesi D, Qiao J, Feng HL. Effect of slow freeze versus vitrification on the oocyte: an animal model. Fertil Steril. 2012;98:752-60 e3.

116. Spinaci M, Vallorani C, Bucci D, Tamanini C, Porcu E, Galeati G. Vitrification of pig oocytes induces changes in histone $\mathrm{H} 4$ acetylation and histone $\mathrm{H} 3$ lysine 9 methylation (H3k9). Vet Res Commun. 2012;36:165-71.

117. Milroy C, Liu L, Hammoud S, Hammoud A, Peterson CM, Carrell DT. Differential methylation of pluripotency gene promoters in in vitro matured and vitrified, in vivo-matured mouse oocytes. Fertil Steril. 2011;95:2094-9.

118. Yan LY, Yan J, Qiao J, Zhao PL, Liu P. Effects of oocyte vitrification on histone modifications. Reprod Fertil Dev. 2010;22:920-5.

119. Suo L, Meng Q, Pei Y, Fu X, Wang Y, Bunch TD, et al. Effect of cryopreservation on acetylation patterns of lysine 12 of histone $\mathrm{H} 4$ (Ach4k12) in mouse oocytes and zygotes. J Assist Reprod Genet. 2010;27: 735-41.

120. Li J, Yang X, Liu F, Song Y, Liu Y. Evaluation of differentially expressed micrornas in vitrified oocytes by next generation sequencing. Int J Biochem Cell Biol. 2019;112:134-40.
121. Monzo C, Haouzi D, Roman K, Assou S, Dechaud H, Hamamah S. Slow freezing and vitrification differentially modify the gene expression profile of human metaphase ii oocytes. Hum Reprod. 2012;27:2160-8.

122. D'Aurora M, Budani MC, Franchi S, Sarra A, Stuppia L, Tiboni GM, et al. Dynactin pathway-related gene expression is altered by aging, but not by vitrification. Reprod Toxicol. 2019:88:48-55.

123. Chamayou S, Bonaventura G, Alecci C, Tibullo D, Di Raimondo F, Guglielmino A, et al. Consequences of metaphase ii oocyte cryopreservation on Mrna content. Cryobiology. 2011;62:130-4.

124. Di Pietro C, Vento M, Guglielmino MR, Borzi P, Santonocito M, Ragusa M, et al. Molecular profiling of human oocytes after vitrification strongly suggests that they are biologically comparable with freshly isolated gametes. Fertil Steril. 2010;94:2804-7.

125. Gao L, Jia G, Li A, Ma H, Huang Z, Zhu S, et al. Rna-Seq transcriptome profiling of mouse oocytes after in vitro maturation and/or vitrification. Sci Rep. 2017;7:13245

126. Huang J, Ma Y, Wei S, Pan B, Qi Y, Hou Y, et al. Dynamic changes in the global transcriptome of bovine germinal vesicle oocytes after vitrification followed by in vitro maturation. Reprod Fertil Dev. 2018;30:1298-313.

127. Jia BY, Xiang DC, Quan GB, Zhang B, Shao QY, Hong QH, et al. Transcriptome analysis of porcine immature oocytes and surrounding cumulus cells after vitrification and in vitro maturation. Theriogenology. 2019;134:90-7.

128. Wang N, Li CY, Zhu HB, Hao HS, Wang HY, Yan CL, et al. Effect of vitrification on the Mrna transcriptome of bovine oocytes. Reprod Domest Anim. 2017:52:531-41.

129. Wu Z, Pan B, Qazi IH, Yang H, Guo S, Yang J, et al. Melatonin improves in vitro development of vitrified-warmed mouse germinal vesicle oocytes potentially via modulation of spindle assembly checkpoint-related genes. Cells. 2019;8.

130. Chen H, Zhang L, Wang Z, Chang H, Xie X, Fu L, et al. Resveratrol improved the developmental potential of oocytes after vitrification by modifying the epigenetics. Mol Reprod Dev. 2019;86:862-70.

131. Ma Y, Pan B, Yang H, Qazi IH, Wu Z, Zeng C, et al. Expression of Cd9 and $\mathrm{Cd} 81$ in bovine germinal vesicle oocytes after vitrification followed by in vitro maturation. Cryobiology. 2018;81:206-9.

132. Wu H, Yu XL, Guo XF, Zhang F, Pei XZ, Li XX, et al. Effect of liquid helium vitrification on the ultrastructure and related gene expression of mature bovine oocytes after vitrifying at immature stage. Theriogenology. 2017;87: 91-9.

133. Shirazi A, Naderi MM, Hassanpour H, Heidari M, Borjian S, Sarvari A, et al. The effect of ovine oocyte vitrification on expression of subset of genes involved in epigenetic modifications during oocyte maturation and early embryo development. Theriogenology. 2016;86:2136-46.

134. Dai J, Wu C, Muneri CW, Niu Y, Zhang S, Rui R, et al. Changes in mitochondrial function in porcine vitrified mii-stage oocytes and their impacts on apoptosis and developmental ability. Cryobiology. 2015;71:291-8.

135. Spricigo JF, Morais K, Ferreira AR, Machado GM, Gomes AC, Rumpf R, et al. Vitrification of bovine oocytes at different meiotic stages using the cryotop method: assessment of morphological, molecular and functional patterns. Cryobiology. 2014;69:256-65.

136. Zhou GB, Zeng Y, Meng QG, Liu Y, Dai YP, Zhu SE, et al. Decreased expression of $\mathrm{Cd} 9$ in bovine oocytes after cryopreservation and the relationship to fertilization capacity. Mol Reprod Dev. 2013;80:451-9.

137. Rao BS, Mahesh YU, Charan KV, Suman K, Sekhar N, Shivaji S. Effect of vitrification on meiotic maturation and expression of genes in immature goat cumulus oocyte complexes. Cryobiology. 2012;64:176-84.

138. Turathum B, Saikhun K, Sangsuwan P, Kitiyanant Y. Effects of vitrification on nuclear maturation, ultrastructural changes and gene expression of canine oocytes. Repr Biol Endocrinol. 2010;8:70.

139. Anchamparuthy VM, Pearson RE, Gwazdauskas FC. Expression pattern of apoptotic genes in vitrified-thawed bovine oocytes. Reprod Domest Anim. 2010:45:e83-90

140. Habibi A, Farrokhi N, Moreira da Silva F, Bettencourt BF, Bruges-Armas J, Amidi $F$, et al. The effects of vitrification on gene expression in mature mouse oocytes by bested quantitative Pcr. J Assist Reprod Genetics. 2010; 27:599-604

141. Succu S, Bebbere D, Bogliolo L, Ariu F, Fois S, Leoni GG, et al. Vitrification of in vitro matured ovine oocytes affects in vitro pre-implantation development and Mrna abundance. Mol Reprod Dev. 2008;75:538-46. 
142. Liang Y, Fu XW, Li JJ, Yuan DS, Zhu SE. DNA methylation pattern in mouse oocytes and their in vitro fertilized early embryos: effect of oocyte vitrification. Zygote. 2014;22:138-45.

143. Cao Z, Zhang M, Xu T, Chen Z, Tong X, Zhang D, et al. Vitrification of murine mature metaphase ii oocytes perturbs DNA methylation reprogramming during preimplantation embryo development. Cryobiology. 2019;87:91-8.

144. Wu G, Jia B, Mo X, Liu C, Fu X, Zhu S, et al. Nuclear maturation and embryo development of porcine oocytes vitrified by cryotop: effect of different stages of in vitro maturation. Cryobiology. 2013;67:95-101.

145. Mohsenzadeh M, Salehi-Abargouei A, Tabibnejad N, Karimi-Zarchi M, Khaliil MA. Impact of vitrification on human oocytes before and after in vitro maturation: a systematic review and meta-analysis. Eur J Obstetrics Gynecol Reprod Biol. 2018;227:19-26.

146. Zhe J, Zhang J, Chen S, Zhang W, Luo C, Zhou X, et al. Causes of oocyte vitrification and its value in assisted reproductive technology. Nan Fang Yi Ke Da Xue Xue Bao. 2019;39:766-71

147. Zhou GB, Li N. Bovine oocytes cryoinjury and how to improve their development following cryopreservation. Anim Biotechnol. 2013;24:94-106.

148. Khalili MA, Shahedi A, Ashourzadeh S, Nottola SA, Macchiarelli G, Palmerini MG. Vitrification of human immature oocytes before and after in vitro maturation: a review. J Assist Reprod Genetics. 2017:34:1413-26.

149. Edgar DH, Gook DA. A critical appraisal of cryopreservation (slow cooling versus vitrification) of human oocytes and embryos. Hum Reprod Update. 2012;18:536-54.

150. Chian RC, Huang JY, Tan SL, Lucena E, Saa A, Rojas A, et al. Obstetric and perinatal outcome in 200 infants conceived from vitrified oocytes. Reprod BioMed Online. 2008;16:608-10.

\section{Publisher's Note}

Springer Nature remains neutral with regard to jurisdictional claims in published maps and institutional affiliations.

Ready to submit your research? Choose BMC and benefit from:

- fast, convenient online submission

- thorough peer review by experienced researchers in your field

- rapid publication on acceptance

- support for research data, including large and complex data types

- gold Open Access which fosters wider collaboration and increased citations

- maximum visibility for your research: over $100 \mathrm{M}$ website views per year

At $\mathrm{BMC}$, research is always in progress.

Learn more biomedcentral.com/submissions 